\title{
Techno-Economic Analysis of Hybrid Photovoltaic/ Diesel Energy System for Oil and Gas Industries in Nigeria
}

\author{
Emmanuel Chinweikpe Obuah ${ }^{1}$, Tamuno-Omie Joyce Alalibo ${ }^{2}$ \\ ${ }^{1,2}$ Electrical Engineering Department, Rivers State University, Nkpolu-Oroworokwo, Port Harcourt, P.M.B. 5080, Rivers State Nigeria
}

\begin{abstract}
This paper focuses on the technical and economic analysis of renewable energy for the sustainability of oil and gas industries in Nigeria, particularly the impact of photovoltaic $(P V)$ renewable energy technology. Two energy generation systems (hybrid $P V / D i e s e l$ with battery storage, and Diesel-Only) configured to serve a18kW AC load for a supposed gas company were examined. HOMER software was used for optimal sizing of system's components and the feasibility analysis. System costs involve investments, replacements and operation and maintenance costs and the characteristics of components are commercially available. The optimization problem is subject to economic and environmental constraints. A comparative analysis between the examined systems found diesel generation to be of low investment cost; however it had some disadvantages like fuel consumption cost and green-house-gas (GHG) emission. The cost of PV components with battery storage device was found to be relatively high, but the system constituted a significant advantage when incorporated with diesel generation. Finally, system with best configuration that has minimum cost and can satisfy the constraints is selected. The study is performed in a special region in South-West of Nigeria.
\end{abstract}

Keywords: HOMER, Hybrid system, Nigeria, Optimization

\section{Introduction}

Human activities have been carried out through the use of energy for decades. Centuries ago, coal fire was used as energy source for light, heat, cooking and for safety and then transportation until the discovery of oil and gas. Since then, most of the technologies utilized have been dependent on these readily available energy resources. However, in the recent years, energy demand has been a major global challenging issue. Most developed countries have redefined and re-engineered their energy production approach and technology through the use of renewable energy resources. These countries are becoming increasing dependent on reliable and secured electricity supplies to support economic growth and sustainable development.

Industrialization is key and central to the economic growth, and it is a desirable conception to improve quality of lives for populace. Electrical energy provides an aid to this. Nigeria is not only the most populous nation in Africa; the country is also rich and endowed with oil and renewable energy resources such as solar PV. Oil accounts for more than a half of total energy consumption in Nigeria while the country's average solar irradiance is about 3.5-7.0 $\mathrm{kWh} / \mathrm{m}^{2} /$ day with an average sunshine hour of 6.5 hours given about $4.851 \times 10^{12} \mathrm{kWh}$ of energy from the sun daily [1] [2]. Most industries however, including oil and gas sector still depend largely on diesel energy generation for their electricity supply. A study by Tyler showed thatof 232 Nigerian based firms, $97 \%$ owned private generators and operated them for $67 \%$ of their production time [3].

Fossil energy generation provides more predictable power on demand, however the operational cost associated with it, such as increase in fuel price, lack of maintenance personnel, [fuel] scarcity and transportation and the environmental impact is relatively high [4].On the other hand, PV systems have distinct environmental advantages for generating electricity over other fossil technologies: the operation of PV systems does not produce any noise, toxic-gas and greenhouse emission, though its initial cost is high and its power is very dependent on the weather conditions [5].However, recently, there has been an increasing interest in PV renewable energy technology all over the world, due to their availability and stability [6] [7].

But no single source of energy is capable of supplying costeffective and reliable power so far. The combined use of multiple power resources can be a viable way to achieve trade-off solutions in terms of costs [8]. This technology is called Hybrid Renewable Energy System (HRES). Various researchers have used several options to design HRES in a most cost effective way. There are some studies that considered the hybrid system such as PV/wind, and designed optimal sizing for components of it [9] [10].

In this study, PV/diesel systems were considered. PV and diesel generation became viable alternatives for power production in Nigeria because of the country's strengths of both conventional and solar renewable energy resources. To mitigate or even cancel out power fluctuations [in the country], energy storage devices, such as storage batteries (SBs) can be employed. SBs can increase the system reserve to coincident with peak load demand thereby reducing operating costs or capital expenditures and increasing their system profit margins [11].

The purpose of the study is to analysis the technical and economic benefit of diesel-only energy generation and $\mathrm{PV} /$ diesel system as well as the environmental impact. The objective is to design a most cost-effective energy system with improved electricity supply using HOMER2.81V software. The study was performed for a selected unit of Agas Company located in Lagos Nigeria. The region has the latitude of $6^{\circ} 27^{\prime} \mathrm{N}$ and longitude of $3^{\circ} 16^{\prime} \mathrm{E}$ as well as altitude

\section{Volume 6 Issue 7, July 2017 www.ijsr.net}




\section{International Journal of Science and Research (IJSR) \\ ISSN (Online): 2319-7064}

Index Copernicus Value (2015): 78.96 | Impact Factor (2015): 6.391

of7 Meters Above Sea Level (MASL) according to information obtained from PVGIS-CMSAF [12].

This research report is organized as follows: section 2 describes the HOMER software; section 3 describes system design configuration. Operation strategy is discussed in section 4, while Problem formulation and system simulation are discussed in section 5 and 6 , respectively. Simulation result analysis is summarized in section 7 , while section 8 give HOMER recommendation for the hybrid system and, finally, section 9 is devoted to conclusion.

\section{HOMER Software}

HOMER is a computer tool that simplifies the task of evaluating design options for both off-grid and grid connected power systems for remote, stand-alone and grid connected systems [13]. HOMER has been developed specifically to meet the needs of renewable energy industry's system analysis and optimization by United State (US) National Renewable Energy Laboratory (NREL) since 1993. HOMER performs three major tasks namely simulation, optimization and sensitivity analysis. In the simulation process, HOMER models a system and determines its technical feasibility and life cycle. In the optimization process, HOMER performs simulation on different system configurations to come out with the optimal selection sorted by Net Present Cost (called lifecycle-cost). In the sensitivity analysis process, HOMER performs multiple optimizations under a range of inputs to account for uncertainty in the model inputs.

\section{System Design}

Consider the configuration shown in Figure 1(a). The system consists of three major power sources: diesel generator, photovoltaic arrays, and storage batteries in addition to inverter which converts $\mathrm{DC}$ voltage to $\mathrm{AC}$, and converters which converts AC voltage to DC. The system may also need a DC-DC boost converter for a steady DC input to be fed into the PV module in all conditions of PV output except when the output is below the minimum threshold level. These components units have different impacts on cost and reliability of the system. In the hybrid generation system, the three power sources were integrated together and complemented each other in order to serve the peak load while satisfying certain criteria. Figure 1(b) shows a dieselonly generation system, where diesel generator is the only components needed for energy generation. The design of the system was based on three considerations: technical, economical, and environmental. The technical aspect was taken into consideration when choosing the design specification and components. For economic consideration, HOMER will be used to simulate and to select the cost effective option. Finally, environmental consideration was taken into account when choosing a location for system mainly the availability of solar data.

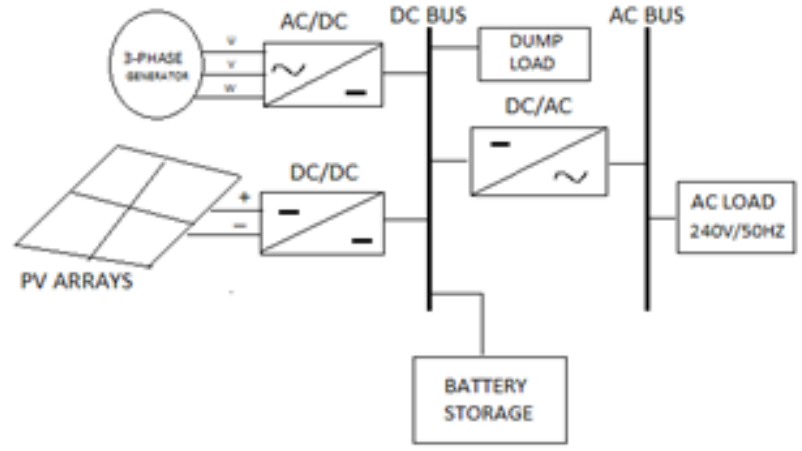

Figure 1(a): Block diagram of a hybrid diesel/PV generation unit

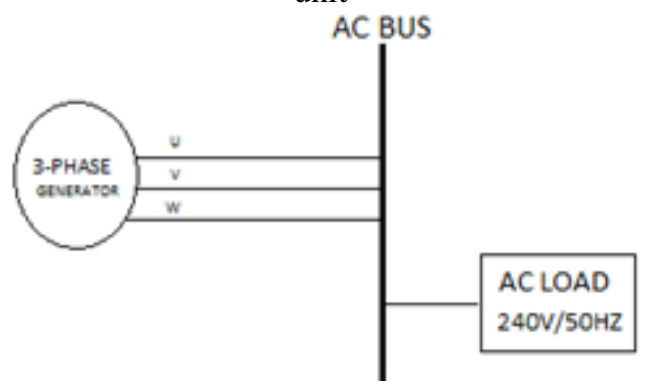

Figure 1(b): Block diagram of a diesel/PV generation unit

\section{Operation Strategy}

Diesel generator system is normally designed to provide predictable power on demand. When incorporated with PV unit as shown in Figure 1(a), PV energy should have the highest priority to feed the loads. The generator is switched ON only when both PV and battery cannot serve the loads. If the total power generated from PV source is insufficient to satisfy the load demand, the battery storage can be discharged to a certain amount of energy to supply the loads. This means that the generator power has the lowest priority to feed the load. In addition, if there is any excess power from PVs, the batteries will be charged to store this extra energy to a certain level of charge for future use and if batteries are charged to the maximum allowed level, excess amount of energy will be wasted in dump load.

\section{Problem formulation}

A reliability of $100 \%$ was assumed in this study. That means, it is desirable that the optimal system meets the load demand, thecosts be minimized and the components have the optimal sizes. An energy balance is calculated for each hour in a year to achieve this. This is done by a developed simulation program where hourly data for solar radiation, ambient temperature and load are inputted to it.

The power generated by the PV panels is given by Equation (1) [14]:

$P_{P V-\text { oUT }}=P_{R-P V} *\left(\frac{G}{G_{r e f}}\right) *\left[1+K_{T}\left(T_{C}-T_{r e f}\right)\right]----(1)$

Where $\mathrm{P}_{\mathrm{PV} \text {-out }}$ is the output power generated from the $\mathrm{PV}$ panel, $P_{R-P V}$ is the $P V$ rated power at reference conditions, $G$ is solar radiation $\left(\mathrm{W} / \mathrm{m}^{2}\right), \mathrm{G}_{\mathrm{ref}}$ is solar radiation at reference conditions $\left(\mathrm{G}_{\mathrm{ref}}=1000 \mathrm{~W} / \mathrm{m}^{2}\right), \mathrm{T}_{\text {ref }}$ is the cell temperature at reference conditions $\left(\mathrm{T}_{\text {ref }}=25^{\circ} \mathrm{C}\right), \mathrm{K}_{\mathrm{T}}$ is temperature 


\section{International Journal of Science and Research (IJSR) \\ ISSN (Online): 2319-7064 \\ Index Copernicus Value (2015): 78.96 | Impact Factor (2015): 6.391}

coefficient of the PV panel $\left[\mathrm{K}_{\mathrm{T}}=-3.7 \times 10-3\left(1 /{ }^{\circ} \mathrm{C}\right)\right]$ for mono and poly crystalline silicon.

Equation (2) is used to calculate the cell temperature $T_{c}$ such that:

$$
T_{C}=T_{a m b}+(0.0256 * G)--------(2)
$$

where $\mathrm{T}_{\mathrm{amb}}$ is the ambient temperature in ${ }^{\circ} \mathrm{C}$. The rated power $\mathrm{P}_{\mathrm{R}-\mathrm{PV}}$ can be calculated using the equation

$$
\left.\left.P_{R-P V}=E_{L} * S_{L}\right) / \eta_{R} * \eta_{V} * P S H\right)-(3)
$$
where $E_{L}$ is daily load energy, $S_{L}$ is stacking factor considered to compensate for resistive and $\mathrm{PV}$-temperature losses, $\eta_{\mathrm{R}}, \eta_{\mathrm{V}}$ are efficiencies of solar charging regulator and bidirectional inverter respectively, and PSH is the peak sun shine hours (numerically equals to daily average of solar radiation at the specified location).

The storage capacity of the battery $(\mathrm{CWh})$ is calculated using Equation (4) [15]:

$$
\left.C_{W h}=\left(E_{L} * A D\right) / \eta_{V} * \eta_{B} * D O D\right)
$$

where DOD is allowable depth of discharge of the battery, $\mathrm{AD}$ is number of autonomy days, and $\eta_{\mathrm{B}}$ is battery efficiency.

The fuel consumption of the diesel generator depends on the rated power of the generator and the actual output power supplied by it. The fuel consumption of the diesel generator $\left(\mathrm{FC}_{\mathrm{G}}\right)$ in $(\mathrm{W} / \mathrm{h})$ is given as:

$$
F C_{G}=A_{G} * P_{G}+B_{G} * P_{R-G}--- \text { (5) }
$$

where $\mathrm{P}_{\mathrm{G}}, \mathrm{P}_{\mathrm{R}-\mathrm{G}}$ are the output power and the rated power of the generator in $(\mathrm{kW})$ respectively. $A_{G}$ and $B_{G}$ are the coefficients of the consumption curve in $(1 / \mathrm{kWh})$ where $A_{G}$ $=0.2461 / \mathrm{kWh}$ and $\mathrm{B}_{\mathrm{G}}=0.081451 / \mathrm{kWh}$ for the diesel generator.

To achieve a viable hybrid system, optimization variables were considered. Optimization variables are sizes of diesel generators $(\mathrm{kW})$, sizes of PV arrays $(\mathrm{kW})$, batteries string and sizes of DC/AC converter $(\mathrm{kW})$, as shown Table 1 .

Net Present Cost (NPC)was chosen as the main criteria for calculation of system cost. In this study, capital cost, replacement cost, operation and maintenance cost were considered. In a null shell, the study intends to consider a cost effective system based on minimum annualized cost, which is 20 years.

Table 1: System optimization variables

\begin{tabular}{|c|c|c|c|}
\hline $\begin{array}{c}P V \\
\text { array }(\mathrm{kW})\end{array}$ & $\begin{array}{c}\text { Generator } \\
(\mathrm{kW})\end{array}$ & $\begin{array}{c}\text { H3000 battery } \\
(\text { strings })\end{array}$ & $\begin{array}{c}\text { Converter } \\
(\mathrm{kW})\end{array}$ \\
\hline 0.000 & 0.00 & 0 & 0.00 \\
\hline 5.500 & 7.50 & 2 & 10.00 \\
\hline 9.500 & 10.00 & 4 & 17.00 \\
\hline 13.500 & 15.00 & 6 & 19.00 \\
\hline 19.000 & 20.00 & 8 & 20.00 \\
\hline 20.000 & 25.00 & 10 & 21.00 \\
\hline
\end{tabular}

\section{System Simulation}

Relevant data were entered into the specific slots provided in the HOMER work environment to perform the technical and economic calculation for a cost effective system. HOMER performs the simulation by comparing the use of diesel-only generator system and diesel/PV system. Input data include solar PV tilt angle, load size, diesel price, and others as stated below. The information presented were used in the homer software to find the optimal hybrid system architecture that can be able to provide electric energy with the cheapest price (that is, Cost of Energy in $\$ / \mathrm{kWh}$ ).

\subsection{Solar Irradiation and PV Array Optimum Angle Input}

The data for the monthly irradiation, taken from PVGIST shown in Table 2 was entered. Four tilt angles- $6.4^{\circ}, 7^{\circ}, 8^{\circ}$, and $10^{\circ}$ were entered including $9^{\circ}$ given by PVGIST. This is to allow HOMER to recommend the best angle that could enhance the collection of peak solar energy for each hour of the year. The azimuth angle of $0^{\circ}$ was entered.HOMER then recommended $10^{\circ}$ for tilt angle

Table 2: Monthly solar irradiation of Amowu-Odofin communityat location: $6^{\circ} 27^{\prime} 0^{\prime \prime}$ North, $3^{\circ} 16^{\prime} 0^{\prime \prime}$ East, Elevation: 7 Meters Above Sea Level (MASL) [12]

\begin{tabular}{|l|r|}
\hline \multicolumn{1}{|c|}{ Month } & $\boldsymbol{H}_{\boldsymbol{*}}$ \\
\hline Jan & 5770 \\
\hline Feb & 6020 \\
\hline Mar & 6220 \\
\hline Apr & 6010 \\
\hline May & 5390 \\
\hline Jun & 4560 \\
\hline Jul & 4470 \\
\hline Aug & 4860 \\
\hline Sep & 5050 \\
\hline Oct & 5200 \\
\hline Nov & 5630 \\
\hline Dec & 5470 \\
\hline Year & 5380 \\
\hline & Yor Irradiation on horizontal plane $\left(\mathrm{Wh} / \mathrm{m}^{2} /\right.$ day $)$ \\
\hline
\end{tabular}

\subsection{Load Input}

The system load is AC [loads], which are classified as critical and non-critical loads. The critical loads constitute about $99 \%$ of the total annual system loads, after adding an increase factor of $10 \%$ to account for future load demand. In this situation, load application varies significantly with solar input, so load demand was annualized to meet the peak load. The average energy consumption profile of the critical load is $251 \mathrm{kWh} /$ day, whereas that of non-critical load is $3.4 \mathrm{kWh} / \mathrm{day}$

\subsection{Component Cost/Size Input}

The systems' components cost includes Capital, Replacement and Operation \& Maintenance (O\&M) as detailed in each section of components input cost and sizes. Capital cost covers the cost of transportation, installation and labor. The O\&M includes maintenance and servicing cost. A diesel price of $\$ 1.00$ was entered. Table 3 shows the conversion rate. HOMER assumes all prices escalate at the same rate; it is not possible to model the escalation of diesel price at different rates. Therefore, calculations are based on 


\section{International Journal of Science and Research (IJSR) \\ ISSN (Online): 2319-7064 \\ Index Copernicus Value (2015): 78.96 | Impact Factor (2015): 6.391}

current prices and do not reflect the effects of possible further increases of the diesel prices. It is however possible to explore the effects of an escalating diesel price by doing a sensitivity analysis on the diesel price alone. Figure 2(a), 2(b), 2(c) and 2(d) show the various components sizes and cost inputs.

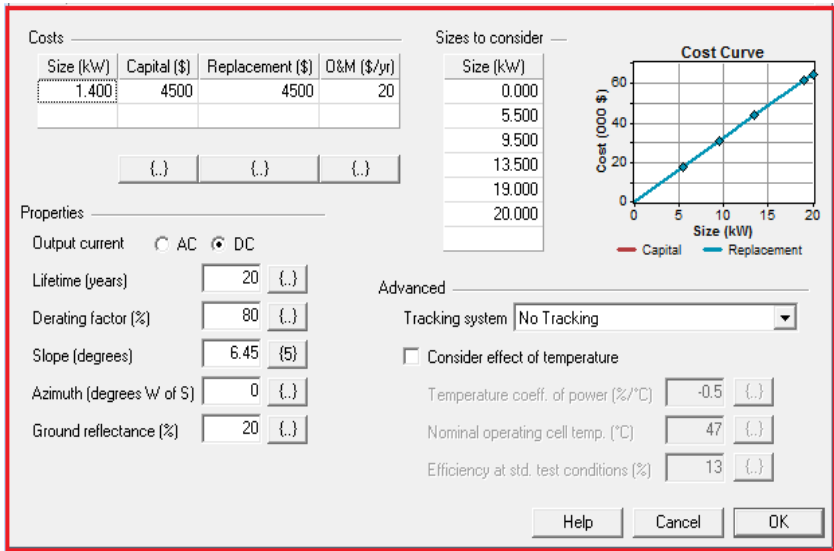

Figure 2(a): Generator sizes and cost Inputs

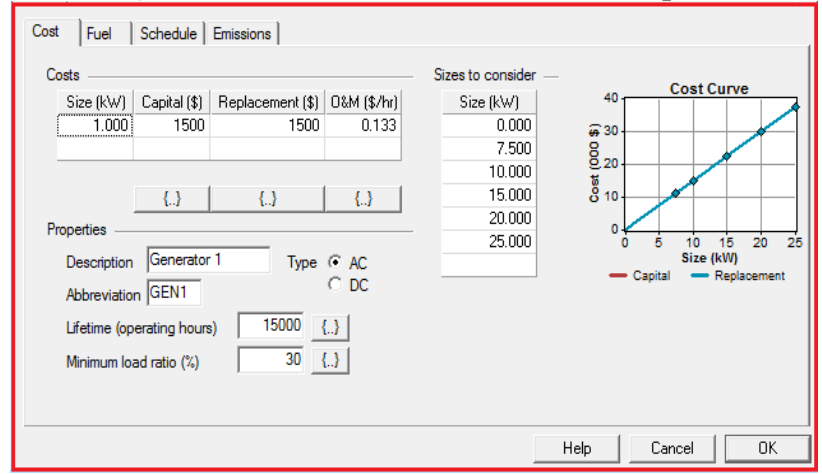

Figure 2(b): PV sizes and cost Inputs

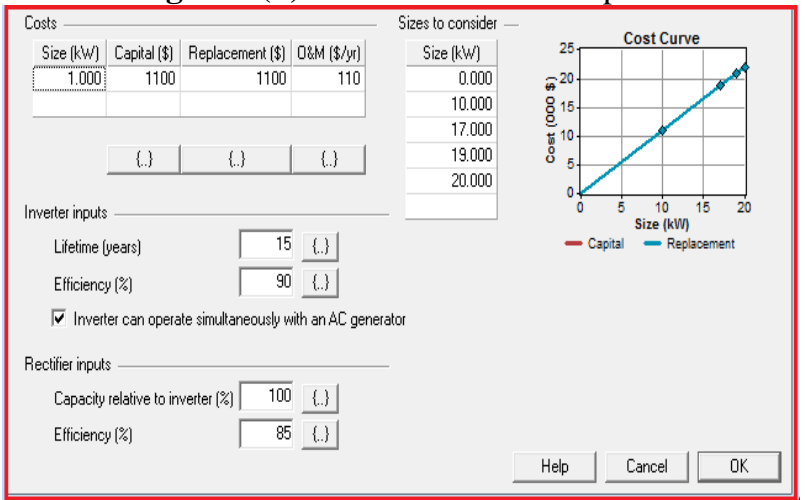

Figure 2(c): Converter Inputs.

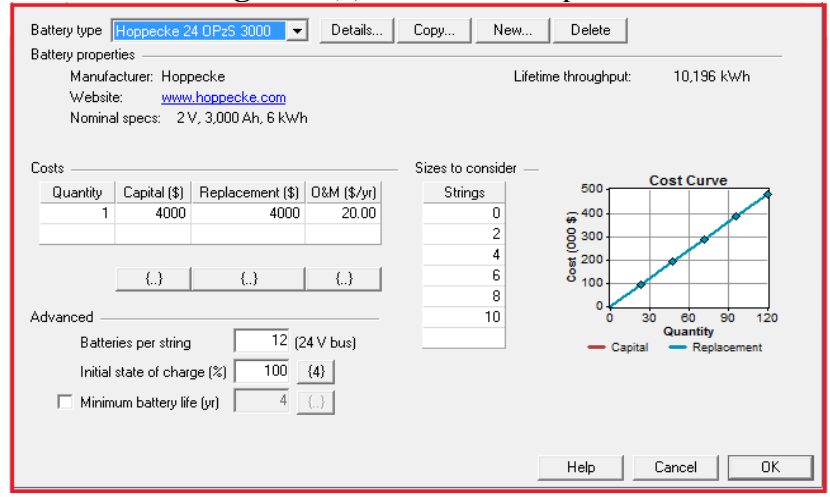

Figure 2(d): Battery Inputs

\section{Simulation and Result Analysis}

HOMER used the data entered in section 5 for simulation and recommends the optimal hybrid system architecture that can meet the criteria. 1080 of 1080 simulations run was completed in 1:03:38 time. Simulations were performed for 20 years of system operation. HOMER assumes all prices escalate at the same rate; it is not possible to model the escalation of diesel price at different rates. Therefore, calculations are based on current prices and do not reflect the effects of possible further increases of the diesel prices. It is however possible to explore the effects of an escalating diesel price by doing a sensitivity analysis on the diesel price alone. The detailed components operational costs of the two systems are shown in Figure 3(a) and 3(b).

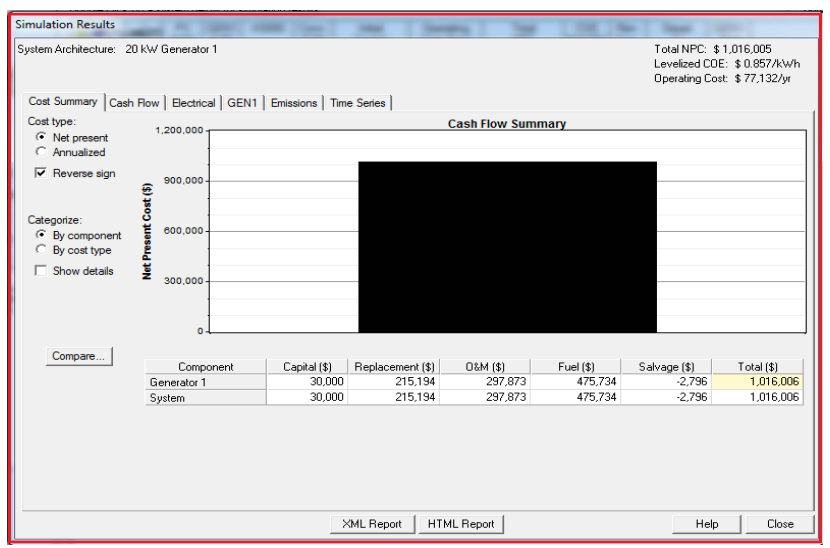

Figure 3(a): Cash flow summary for diesel generation configuration

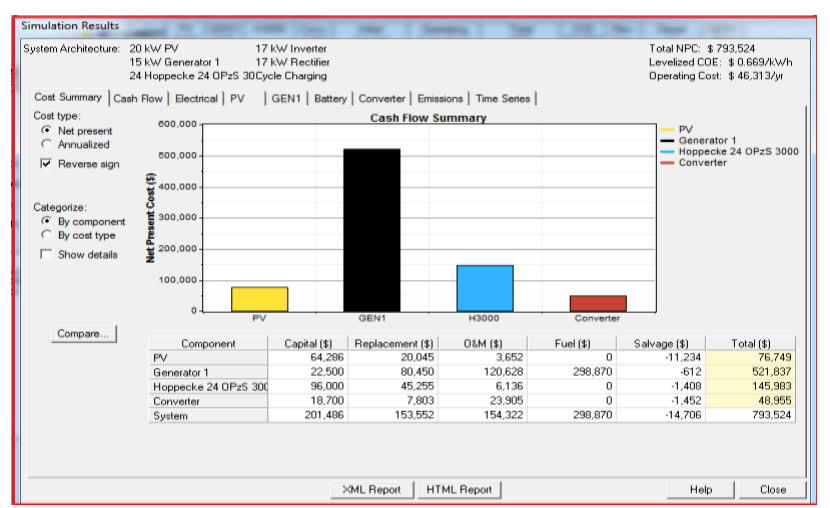

Figure 3(b): Cash flow summary for diesel/PV generation configuration

\subsection{Economic analysis}

From the results above, the optimal hybrid diesel-PVbattery-battery system has a NPC of $\$ 793524$. The O\&M cost of the optimal hybrid system is $\$ 154.233$, the replacement cost is $\$ 153.552$, fuel cost is $\$ 298.870$. The NPC of the existing diesel generator is $\$ 1,016.005$, the O\&M cost is $\$ 297.873$, replacement cost is $\$ 215.194$ and fuel cost is $\$ 474.735$. The total system cost of the optimal system was reduced due to the integration of PV component. Though the capital cost of the optimal is high compared to diesel generation system, PV integration has contributed in reducing the system's O\&M cost by $39.9 \%$; Cost of Energy (COE) in $\$ / \mathrm{kWh}$ by $21.9 \%$ and fuel cost by $37.1 \%$. This is good economic benefit of PV generation.

\section{Volume 6 Issue 7, July 2017 www.ijsr.net}




\section{International Journal of Science and Research (IJSR) \\ ISSN (Online): 2319-7064 \\ Index Copernicus Value (2015): 78.96 | Impact Factor (2015): 6.391}

\subsection{Environmental analysis}

Green-house-gas pollutants include carbon dioxide, carbon monoxide, unburned hydrocarbons, particulate matter, sulfur dioxide and nitrogen oxides. The total GHG emission for $\mathrm{PV} /$ diesel/battery hybrid system is $100642 \mathrm{~kg} / \mathrm{year}$. This is reduced compared to diesel-only configuration which is $8101.3 \mathrm{~kg} / \mathrm{year}$ due to $\mathrm{PV}$ integration. This again, is another good thing about renewable energy resources, which is minimizing GHG emission.

\subsection{Technical analysis}

The hybrid system PV unit delivered a maximum power of $19.8 \mathrm{~kW}$, total energy production of $31.773 \mathrm{KWh} /$ year and alsoa maximum output for the generator unit is $15 \mathrm{KW}$, diesel consumption is 23.380 liters per year and energy production is $70.817 \mathrm{KWh} /$ year. For diesel-only generation, the maximum power generated is $17.5 \mathrm{KW}$; diesel consumption is 37.215litre per year and energy production $92.796 \mathrm{KWh} /$ year. The diesel generator provided more predictable power on demand; however the hybrid system delivered the maximum power necessary to cover the load peaks which is $18 \mathrm{KW}$ when the other source is not available. Again fuel consumption of the hybrid system has been reduced due to the use of $\mathrm{PV}$ component. The power generated by the PV arrays contributed $31 \%$ of the total power generated by PV/diesel/battery hybrid system. Table 3 shows summary of HOMER simulation carried out for hybrid PV/diesel/battery system and diesel-only systems.

Table 3: Summary of simulation result

\begin{tabular}{|c|c|c|c|}
\hline & $\begin{array}{c}\text { Hybrid PV } \\
\text { diesel/Battery }\end{array}$ & $\begin{array}{c}\text { Diesel } \\
\text { only }\end{array}$ & Remark \\
\hline Total & $\$ 7935.24$ & $\$ 1,0160.05$ & $\begin{array}{c}\text { NPC to } 21.89 \% \text { reduced } \\
\text { due to PV penetration }\end{array}$ \\
\hline $\begin{array}{c}\text { Energy } \\
\text { Produced }\end{array}$ & $\begin{array}{c}102.590 \mathrm{KWh} \\
\text { per year }\end{array}$ & $\begin{array}{c}92.796 \mathrm{KWh} \\
\text { per year }\end{array}$ & $\begin{array}{c}\text { Additional } 9.794 \mathrm{KWh} / \\
\text { year produced }\end{array}$ \\
\hline GHG & $\begin{array}{c}65530.3 \mathrm{~kg} \\
\text { per year }\end{array}$ & $\begin{array}{c}100642 \mathrm{~kg} \\
\text { per year }\end{array}$ & $\begin{array}{c}34.9 \% \text { reduction } \\
\text { due to PV }\end{array}$ \\
\hline
\end{tabular}

\section{HOMER Recommendation}

HOMER recommended configurations with optimal output for Diesel-PV-Battery system. These can be seen fromFigure 4. The specifications for thesystem's components were given as well.

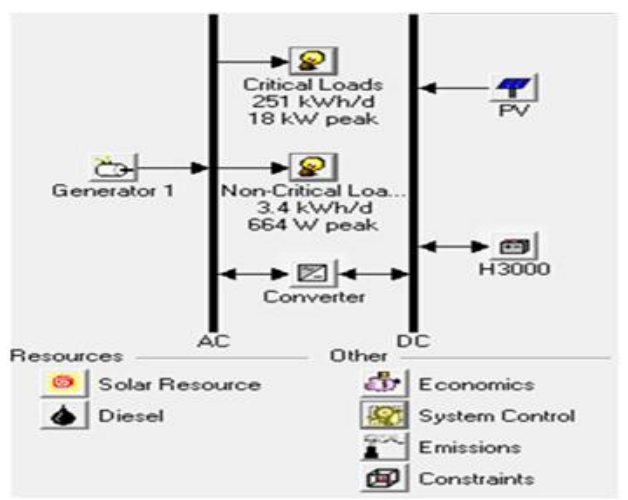

Figure 4: HOMER optimal hybrid diesel-PV-batter system configuration.

\subsection{Module Type}

Table 4below shows the specification given for the real system. The specifications of the module were obtained under the Standard Test Conditions (STCs) that is, 1000 W/m solar irradiance, 1.5 Air Mass, and cell temperature of $25^{\circ} \mathrm{C}$. The PV system have 40 modules in parallel and 2 in series to give a combination that will produced a close output system voltage of $1000 \mathrm{Vdc}$. Monocrystalline module was selected because of efficiency and rigidity.

\subsection{Diesel Generator}

The maximum power needed in the utility unit of the company is $18 \mathrm{~kW}$. In selecting a diesel generator, the generator should have a maximum power necessary to cover the load peaks that may occur in the factory, and also supply power when the other source is not available. However, a diesel generator with maximum power output of $15 \mathrm{KW}$ was recommended by HOMER and that is when there is input from solar PV system.

Table 4: PV Model Specifications

\begin{tabular}{|c|c|}
\hline Model Type & SW 250 Mono \\
\hline Peak Power & $250 \mathrm{Wp}$ \\
\hline Maximum Power Point Voltage(Vmpp) & $31.1 \mathrm{~V}$ \\
\hline Maximum Power Point Current(Impp) & $8.05 \mathrm{~A}$ \\
\hline Open Circuit Voltage(Voc) & $37.8 \mathrm{~V}$ \\
\hline Short Circuit Current(Isc) & $8.28 \mathrm{~A}$ \\
\hline Maximum System Voltage & DC $1000 \mathrm{~V}$ \\
\hline Maximum Reverse Current & $16 \mathrm{~A}$ \\
\hline Temperature Co-efficient of Isc (TK Isc) & $0.042 \% / /{ }^{\circ} \mathrm{C}$ \\
\hline Temperature Co-efficient of Voc(TK Voc) & $-0.33 \% /{ }^{\circ} \mathrm{C}$ \\
\hline Temperature Co-efficient of Pmax(TKPmax) & $-0.45 \% /{ }^{\circ} \mathrm{C}$ \\
\hline Normal Operating Cell Temperature & $47^{\circ} \mathrm{C}$ \\
\hline Weight & $21.2 \mathrm{~kg}$ \\
\hline Length & $1675 \mathrm{~mm}$ \\
\hline Width & $1001 \mathrm{~mm}$ \\
\hline Height & $34 \mathrm{~mm}$ \\
\hline
\end{tabular}

\subsection{Inverter}

Converter incorporates an inverter, used to convert DC power to $\mathrm{AC}$ and a rectifier, used to rectify $\mathrm{AC}$ current to DC. Since PV panel only produces DC voltage,inverter is needed to convert the DC voltage from the PV array, to AC voltage for the AC loads. On the other hand, boost DC-DC converter could be used to supply DC current to charge batteries or as a condition system for the inverter to feed a steady DC input into the PV module in all conditions of PV output except when the output is below the minimum threshold level.HOMER recommended a 98\% efficiency inverter and rectifier of $17 \mathrm{KW}$.

\subsection{Storage Battery}

The battery is a $24 \mathrm{Vdc} / 3000 \mathrm{Ah} 30 \mathrm{Cycle}$ with a total of 24 in number, 2 parallel strings with 12 batteries in each string 


\section{International Journal of Science and Research (IJSR) \\ ISSN (Online): 2319-7064}

Index Copernicus Value (2015): 78.96 | Impact Factor (2015): 6.391

\section{Conclusion}

In this study, a supposed autonomous hybrid $\mathrm{PV} /$ diesel/battery system, comprising of a $15 \mathrm{~kW}$ diesel generator, $20 \mathrm{~kW}$ of PV energy penetration, in addition to a $17 \mathrm{~kW}$ converter, was designed. The system demonstrated to be optimal when compared to a diesel-only generation unit of $20 \mathrm{~kW}$ to serve a load of $18 \mathrm{~kW}$ (peak demand) for 20 years period of operation. The optimal system became economically feasible at a diesel price of $\$ 1.00$ per liter and $10^{\circ} \mathrm{PV}$ array angle. The hybrid system was designed for special location in South West of Nigeria. This region has a typical situation for many similar regions around the world. In the study, 24VDC/3000Ahbattery was employed as the energy storage device. Optimal combination of components was achieved by HOMER software. The numerical models developed using the HOMER software package proves to be an efficient and flexible tool for optimum sizing of hybrid power systems based on renewable sources. In the future work of this study, uncertainty factors such as change in fuel price and solar radiation would be taken into account in calculating system reliability indexes. Wind energy resources could be incorporate into the system to further minimize fuel need, and substantially keep the NPC to a reasonable value. Investor in Nigeria and other regions with similar climate condition can also explore the viability of hybrid PV system for industrial uses.

\section{References}

[1] A. S. Sambo, "Matching Electricity Supply with Demand in Nigeria", International Association for Energy Economics,pp.32-33, 2008.

[2] K. Karolis, M. Rasa, R. O. Gaisva, R. Vytauta, "Solar Energy Implementation in Nigeria", rudar.ruc.dk 2008. [Online] Available: www.http://rudar.ruc.dk.

[3] G. Tyler, "Nigeria: Public and Private Electricity Provision as a Barrier to Manufacturing Competitiveness", International Bank for Reconstruction and Development, 2002. [Online] Available: http://www-wds.worldbank.org. [Accessed: Jan. 15, 2017]

[4] R. Mayfield, Photovoltaic Design and Installation for Dummies, Wiley Publishing, Inc., Indiana, 2010.

[5] S. H. Eyad, "Techno-Economic Analysis of Autonomous Hybrid Photovoltaic-Diesel-Battery System”. Science Direct,13(3), pp.143-150, 2009.

[6] S. A. Rehman, "Study of a Solar PV-Diesel-Battery Hybrid Power System for a Remotely Located Population near Rafha, Saudi Arabia”, Energy, 35(12), pp. 4986-4995, 2010.

[7] S. Twaha, M. H. Idris, M. Anwari, A. Khairuddin, "Applying Grid-Connected Photovoltaic System as Alternative Source of Electricity to Supplement Hydro Power instead of using Diesel in Uganda", Energy 37(1), pp. 185-194, 2012.

[8] J. Ami, S. Mohammad, "Battery Storage Systems in Electric Power Systems”. IEE Explore, pp.1-3, 2006.

[9] A. M. Kassem, A. M. Yousef, "Robust Control of an Isolated Hybrid Wind-Diesel Power System using Linear Quadratic Gaussian Approach", International
Journal of Electrical Power \&amp, Energy Systems, 33, pp. 1092-1100, 2011.

[10] M. Marzband, A. Sumper, O. Gomis-Bellmunt, P. Pezzini, M. Chindris, "Frequency Control of Isolated Wind and Diesel Hybrid Microgrid Power", Power Engineering, Department of Energy and Environment Chalmers University of technology, Goteborg, Sweden 2005.

[11]A. Maczulak, Renewable Energy: Sources and Methods, Facts on File Inc., New York, 2010.

[12]PVGIS, 2015-2016, [Online]. Available: http://re.jrc.ec.europa.eu/pvgis. [Accessed: Dec. 10, 2016]

[13]HOMER user Guide, 2016. [Online]. Available: http://homerenergy.com. [Accessed: Nov. 21, 2016].

[14] A. K. Daud, M.S. Ismail, "Design of Isolated Hybrid Systems Minimizing Costs and Pollutant Emissions" Renewable Energy, 44, pp. 215-224, 2012.

[15] T. Khatib, A. Mohamed, K. Sopian, M. Mahmoud, "Optimal sizing of building integrated hybrid PV/diesel generator system for zero load rejection for Malaysia" Energy and Buildings, 43(12), pp. 3430-3435, 2011.

\section{Author Profile}

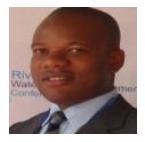

Emmanuel Chinweikpe Obuah was born in Nigeria He obtained B.Eng(Hons) in Electronic and Electrical Engineering from University of Sunderland in 2010; and $\mathrm{Msc}$ in Electrical Power Engineering from Northumbria University in Newcastle Upon Tyne in 2012. He is currently a research student at the University of Nigeria, Nsukka. His research interest is in Energy and Environment (Wind, Solar),and Electrical Machines. He is a lecturer in the Department of Electrical Engineering, Rivers State University, Port Harcourt, Nigeria. He is a registered Engineer with Council for Regulation of Engineering in Nigeria (COREN), a corporate member of Nigerian Society of Engineers (NSE) and Associate Member of Institute of Engineering and Technology (IET)

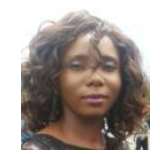

Tamuno-Omie Joyce Alalibo received her B.Tech degree in Computer Engineering from Rivers State University of Science and Technology, Port Harcourt, Nigeria in 2007and also her M.Sc degree in Information and network security from Kingston University London, United Kingdom in 2013. She is a registered Engineer with Council for Regulation of Engineering in Nigeria (COREN) and a corporate member of Nigerian Society of Engineers (NSE). She is currently a lecturer in the Department of Electrical Engineering, Rivers State University, Port Harcourt, Nigeria.

\section{Volume 6 Issue 7, July 2017 www.ijsr.net}

